\title{
IMPROVING MEAL CONTEXT IN NURSING HOMES: IMPACT OF FOUR STRATEGIES ON FOOD INTAKE AND MEAL PLEASURE
}

Camille Divert ${ }^{123}$, Rachid Laghmaoui ${ }^{4}$, Célia Crema ${ }^{4}$, Sylvie Issanchou ${ }^{123}$, Virginie Van Wymelbeke ${ }^{4}$, Claire Sulmont-Rossé ${ }^{123}$

${ }^{1}$ INRA, UMR1324, Centre des Sciences du Goût et de l'Alimentation, F-21000 Dijon, France

${ }^{2}$ CNRS, UMR6265, Centre des Sciences du Goût et de l'Alimentation, F-21000 Dijon, France

${ }^{3}$ Université de Bourgogne, Centre des Sciences du Goût et de l'Alimentation, F-21000 Dijon, France

${ }^{4}$ CHU Champmaillot, Unité de Recherche Service de Médecine Interne Gériatrie, Dijon, France

Correspondence to be sent to: Claire Sulmont-Rossé, UMR CSGA, INRA, 17 rue Sully, BP 86510, 21065 Dijon Cedex, France, sulmont@dijon.inra.fr 


\section{ABSTRACT}

In France, in most nursing homes, the composition of menus, the time and the place at which meals are served, the choice of one's place at the table are imposed on residents. Yet, the act of eating cannot be restricted to nutritional and sensory aspects alone. It also includes a psycho-affective dimension, which relates to the context in which the meal is served. We tested the impact of four contextual factors, considered individually, on food intake and meal pleasure in elderly people living in nursing homes: the way the main course was named on the menu, the size and the variety of portions of vegetables served to residents, the presence or not of condiments in the middle of the table and the presence or not of elements to modify the surrounding such as an decorative object on the table or background music. Twelve experimental meals were served to 42 nursing home residents. For each factor, we compared a control condition with two experimental conditions. Our study showed that changing a single contextual element of the meal in nursing homes could be sufficient to improve residents' satisfaction with their meals and increase the quantities of meat or vegetables consumed, as long as this factor had a direct impact on what was going to be consumed (increased variety on the plate, condiments on the table). Factors affecting the context of the meal (names of dishes, decor) proved to be ineffective. Given the budgetary constraints faced by nursing homes, this study proposes interesting and inexpensive ideas to increase satisfaction with meals and food intake in elderly people who are dependent on others for their meals. 


\section{Introduction}

Whether voluntary or not, admission to a nursing homes is a major turning point in the life of an elderly person, as it modifies his habits and his physical and social environment. Furthermore, the elderly person must adapt to rules set by the establishment, notably with regard to food. In France, in the vast majority of nursing homes, the composition of menus, the time and the place of meals, even the choice of one's place at the table are imposed on residents. Several studies have reported a high prevalence of malnutrition in nursing homes. In France, 15 to $38 \%$ of elderly people living in nursing homes suffered from malnutrition compared with 4 to $10 \%$ of elderly people living at home (HAS, 2007). Malnutrition, a recognized disease in the elderly, corresponds to a deficiency in nutritional intake, in terms of calories and/or nutrients and micronutrients. The many consequences include muscle wasting and impaired immune defences. An elderly person with malnutrition is at risk of entering a vicious spiral: without prevention and without care, malnutrition leads to decreased mobility, an increased risk of falls or fractures, increased vulnerability to infectious diseases and exacerbation of chronic diseases, which in turn contribute to loss of appetite and exacerbated malnutrition (Ferry et al., 2012). Without presuming the causal relationship between dependence and malnutrition, it is clear that despite the resources deployed for the support of dependent elderly persons, the risk of malnutrition remains high in this population.

The act of eating cannot be restricted to nutritional aspects alone (i.e., the satisfaction of a physiological need) and a sensory aspect (i.e., the pleasure procured by enjoyment of the organoleptic properties of food). It also includes a psycho-affective dimension, which is related to the 'context' of the food intake. Rozin and Tuorila (1993) defined this 'context' as being the "set of events and experiences that are not part of the reference event [i.e., eating a target food] but have some relationship to it". These authors further acknowledged that 
"contextual influences may be simultaneous with the reference event" (contextual factors physically present when eating a food) or "may precede it" (mental representation of the reference event may form a context that influences current consumption). The impact of the context on the act of eating has been clearly shown in adults. Several studies have shown the impact of the physical and social context of meals on food choice, enjoyment of foods, the duration of meals and the quantities consumed (for a review, see Meiselman, 2006; Wansink, 2006).

Several authors have underlined the importance of the context of meals in nursing homes on the appetite and food intake of residents (Abbasi \& Rudman 1994; Wikby \& Fägerskiöld 2004; Nieuwenhuizen, Weenen, Rigby, \& Hetherington, 2009; Nijs, de Graaf, van Staveren, \& de Groot, 2009; Leslie, 2011; Philpin, 2011). However, a limited number of studies have quantified the impact of contextual improvement on food intake and/or on the nutritional status of institutionalized people (Abbott et al., 2013). Some of them focused on the effectiveness of a single change such as providing smaller portions (Cluskey \& Dunton, 1999), switching from a prepared tray to a bulk service (Shatenstein \& Ferland, 2000), having the staff sharing the meals with the residents (Charras \& Frémontier, 2010), enhancing the colour contrast of the crockery that food was served on (Dunne, Neargarder, Cipolloni, \& Cronin-Golomb, 2004), improving lighting (Brush, 2002) or diffusing music in the dining room (Ragneskog, Kihlgren, Karlsson, \& Norberg, 1996; Thomas \& Smith, 2009). Six studies assessed large-scale changes which mainly aimed at shifting the dining room from an institutional appearance to more home-like setting (Table 1). Four of these studies reported that an improvement in the context of the meal could have a positive impact on food intake (Elmstâhl, Blabolil, Fex, Küller, \& Steen, 1987; Desai, Winter, Young, \& Greenwood, 2007; Nijs, de Graaf, Kok, \& van Staveren, 2006) and/or body weight (Mathey, Vanneste, de Graaf, de Groot, \& van Staveren, 2001; Nijs et al., 2006). Kenkmann, Price, Bolton, and Hooper 
(2010) observed no impact of a one-year intervention on weight, despite a slight (but not significant) reduction in weight loss in intervention homes compared to control homes. In these studies (Table1), the context of meals in nursing homes was improved 'as a whole', by improving the food service, the decor of the dining room, the crockery, and even the menus proposed. As a result, even though some of these studies showed that improving the context had a positive effect on the nutritional status of residents, such improvements are difficult to implement in the field because they are difficult to reconcile with the constraints of nursing homes in terms of cost and personnel.

\section{Table 1 about here}

The aim of the present study was to test the impact of four contextual factors, implemented individually, on food intake and meal pleasure in elderly people living in nursing homes. We thus tested the way the main course was named on the menu (dish name), the size and the variety of portions of vegetables served to the residents (portion), the presence or not of condiments in the middle of the table (condiment) and the presence or not of elements to modify the atmosphere, such as an decorative object on the table or background music (surrounding). These factors actually correspond to some of the contextual factors listed by Rozin and Tuorila (1993) (dish name: food label, expectations; portion: weight, variety; condiment: culinary context, simultaneous chemosensory context; surrounding: effects of surroundings). For each of these factors, we compared a control condition, corresponding to the usual context of the nursing homes, with two experimental conditions. The conditions tested were chosen so that they could be easily applied in nursing homes in case they proved to be effective. 


\section{Material and method}

\subsection{Experimental design}

For each factor (dish name, portion, condiment and surrounding), we compared a control condition with two experimental conditions.

Dish name. We compared one control condition in which the name on the menu corresponded to the dish served ("Sauteed pork and potatoes") with a condition in which the name of the dish suggested better quality meat ("Roast pork with gravy with potatoes" - condition name + ) and a condition in which the name on the menu suggested a gastronomic restaurant (“Mijoté de porc à la Belle Fontaine et sa moutarde à l'ancienne" - condition name ++ ). At the start of each meal, the participants received a menu with for the main course, the name corresponding to the condition tested (this menu was read to visually-impaired participants by the experimenter).

Portion. We compared a control condition in which the portions served for the main course corresponded to the portions recommended by the GEMRCN $\left(2007^{1}\right)(100 \mathrm{~g}$ of meat and 150 $\mathrm{g}$ of green beans) with a condition in which the participants themselves chose the quantity of meat and green beans they wished to eat (condition size choice) and with a condition in which the participants were given $100 \mathrm{~g}$ of meat and two small portions of vegetables ( $75 \mathrm{~g}$ of green beans and $75 \mathrm{~g}$ of zucchinis - condition variety).

Condiment. We compared one control condition in which the participants had the usual condiments supplied by the nursing homes (salt, pepper, mustard) with a condition in which they four additional condiments (butter, vinaigrette, mayonnaise, tomato sauce - condition

\footnotetext{
${ }^{1}$ The GEMRCN (« Groupement d'Etude des Marchés en Restauration Collective et de Nutrition ») is an official text issued by the French government so as to provide a framework for the nutritional quality of meals served in institutions.
} 
condiment + ) and with a condition in which they had eight additional condiments (the four previous ones and garlic, shallot, parsley, lemon - condition condiment ++ ). These condiments were presented in bowls placed in the middle of the table. The participants were free to help themselves to condiments whenever they wished during the meals (participants with functional disorders could ask the experimenter for help).

Surrounding. We compared a control condition in which the context of the meal was the usual context of the nursing home with a condition in which the participants could choose two decorative objects to put on their table (condition decor) and with a condition in which the participants could choose the music they wished to listen to during the meal (condition music). In the condition decor, the participants were allowed to choose two objects of decor from two types of table cloths, two types of bread basket, four bouquets of flowers and four water carafes (this choice was made one week in advance, from photographs). In the condition music, the participants could choose the music they wished to hear from a list of 70 pieces that they were given at the start of the meal. The experimenter played the pieces selected by the residents throughout the meal.

The menus, the names of dishes, the condiments, the objects of decor and the styles of music proposed were selected using the results of a preliminary study conducted in residents of nursing homes who were different from the participants of the present study. This preliminary study comprised individual interviews on the context of meals and improvements that could be made.

\subsection{Participants}

Three nursing homes (A, B, C) took part in our study. Altogether, 42 residents were recruited, 12 in establishments A and B and 18 in establishment C (13 men and 29 women; mean age: 86.6 years; age range: 71 to 99 years). Residents with an allergy to any of the foods in the 
study and those on a prescribed diet were not included, neither were residents with a severe cognitive impairment, with dysphagia and those with an acute episode of disease at the time of the study. In order to be as close as possible to the usual conditions of meals, we recruited residents who had their meals at the same table (in the three establishments, the residents had a fixed place at a fixed table in the dining room). For reasons of logistics and in order to balance the order of presentation, the residents of establishment $\mathrm{C}$ were divided into two groups of 9 participants. In accordance with current legislation, the protocol of the study was submitted to and approved by the ethics committee (Comité de Protection des Personnes Est I (ANSM \#2011-A01652-39). After being informed about the organization of the study, the residents who volunteered to take part signed a consent form. Elderly people with a low cognitive status were explained the study in simple terms, fitting with their level of understanding. If the elderly person did not manifest a refusal to participate in the study, the study was explained to his/her tutor who countersigned the consent form. All of the participants were thanked for their participation with a celebratory meal organized at the end of the study and a gift.

\subsection{The food products}

Each factor was associated with a menu composed of a starter, a main course, a dairy product and a dessert; the menu was strictly the same in the three conditions (Table 2). An alternative product was proposed to residents with chewing problems (raw vegetables replaced with soup for $22 \%$ of participants) or problems with bowel transit (rice replaced with pasta for $14 \%$ of participants or with a vegetable for $18 \%$ of participants).

\section{Table 2 about here}

Grated carrots and grated celery root (Carrefour $\left.{ }^{\circledR}\right)$ were seasoned three hours before each meals with ready-made sauces (Carrot: light vinaigrette Amora ${ }^{\circledR}, 240$ g/kg; celery: raw- 
vegetable salad sauce Benedicta ${ }^{\circledR}, 480 \mathrm{~g} / \mathrm{kg}$ ) and then kept at $4^{\circ} \mathrm{C}$ until served. For certain participants, the raw vegetables were replaced with vegetable soup (Knorr ${ }^{\circledR}$ ). The main courses (sautéed pork with potatoes; blanquette of veal and rice; hake filet and rice; guinea fowl in sauce) were supplied by the company Cecab D’Aucy® and packed in individual trays. For the factor portion, the green beans (extra-fine frozen green beans, Carrefour ${ }^{\circledR)}$ were cooked for 35 minutes in salted $(2.5 \mathrm{~g} / \mathrm{l})$ boiling water then stir fried in a frying pan in garlic and parsley butter Carrefour $\left(50 \mathrm{~g} / \mathrm{kg}\right.$; Carrefour $\left.{ }^{\circledR}\right)$. The zucchinis (frozen zucchinis, Carrefour $\left.{ }^{\circledR}\right)$ were cooked in a pressure cooker for 14 minutes, then stir fried in a frying pan with garlic and parsley butter $(60 \mathrm{~g} / \mathrm{kg})$ and salted $(2 \mathrm{~g} / \mathrm{kg})$. The components of the main course were reheated in a bain-marie to the serving temperature between 70 and $80^{\circ} \mathrm{C}$. For the dairy product, the participants could choose between camembert (President $\left.{ }^{\circledR}\right)$, Comté (Entremont $\left.{ }^{\circledR}\right)$ or yoghurt $\left(\right.$ Danone $\left.{ }^{\circledR}\right)$. The cheeses were served at room temperature while the yoghurts were stored at $4{ }^{\circ} \mathrm{C}$ until served. The stewed apple (Andros $\left.{ }^{\circledR}\right)$ and canned fruit in juices (Carrefour $\left.{ }^{\circledR}\right)$ were stored at $4{ }^{\circ} \mathrm{C}$ until served.

For the condiments factor, the products used were: butter Elle\&Vire ${ }^{\circledR}$, mayonnaise Amora ${ }^{\circledR}$, vinaigrette Carrefour ${ }^{\circledR}$, tomato sauce Saint-Eloi ${ }^{\circledR}$, chopped garlic Derigal ${ }^{\circledR}$, chopped shallot Derigal®. The parsley was purchased fresh and chopped on the morning of each session. The lemons were cut into quarters. The mayonnaise and butter were stored at $4^{\circ} \mathrm{C}$ until served. The tomato sauce was served hot (approximately $70^{\circ} \mathrm{C}$ ). The other products were served at room temperature.

\subsection{Procedure}

The residents were invited to take part in 12 lunches at a rhythm of one lunch per week. These meals took place at the same time, in the same room, using the same crockery as the usual meals served by the establishment. The participants sat at their usual table. The meal 
was then served in accordance with the usual serving rhythm of the establishment. For the first helping, the weights of the portions served corresponded to the weights recommended by the GEMRCN (2007) for meals served in institutions for the elderly in France: $100 \mathrm{~g}$ for the grated raw vegetables, $250 \mathrm{~g}$ for the soup, $100 \mathrm{~g}$ for the meat or fish, $200 \mathrm{~g}$ for the rice or potatoes, $150 \mathrm{~g}$ for the vegetables, $40 \mathrm{~g}$ for the cheese, $100 \mathrm{~g}$ for the yoghurt and $100 \mathrm{~g}$ for the dessert. A second helping was systematically proposed to participants who finished their plate (the weight of the second helping corresponded to one half of the weight of the first helping). The twelve meals were split into two series of six meals. During each series, the residents were exposed to two factors $\times$ three conditions. The factors were alternated in such a way that the same menu was served every two weeks. Each series included a factor focused on the main course (dish name or portion) and a factor concerning the meal (surrounding or condiment). Each of the four possible combinations was attributed to one of the four groups of participants (establishment $\mathrm{A}$; establishment $\mathrm{B}$; group 1 in establishment $\mathrm{C}$; group 2 in establishment C). Each series started and ended with a control condition. For each factor, the order in which conditions were presented was balanced in such a way that the control condition appeared as often at the start as at the end of a series and that the two experimental conditions appeared the same number of times in each intermediate position.

\subsection{Measurements}

The outcome measurements were the following:

- Before lunch, participants rated their feeling of hunger on a 7-point scale ranging from "I am not at all hungry" to "I am extremely hungry". As contextual changes could be perceived (dish name, variety, condiment, decor) or were explained to the participants (size choice, music) before beginning the meal, we expected a possible effect on hunger for these changes. 
- During lunch, food intake was measured by weighing the plates before and after consumption (SOEHNLE scales, precision: $\pm 1 \mathrm{~g}$ ). This was done for each participant and for each meal course. The consumption of water, wine and bread were not assessed as these were not served individually, but placed in the middle of the table and available to all.

- For the factor condiment, an experimenter in the room noted for each participant the type and the quantity (number of spoons or number of units) of condiments consumed.

- At the end of the lunch, the participants evaluated their enjoyment of the meal on a 7-point scale ranging from "I didn't like it at all" to "I enjoyed it very much", each point being associated with a smiley (Maître, Symoneaux, \& Sulmont-Rossé, 2012).

During the study, these measurements were done for each participant. However, at the end of the study, the cognitive status of each participant was evaluated using the Mini Mental Scale Examination (MMSE) (Folstein, Folstein, \& McHugh, 1975). The MMSE screens for cognitive impairment: scores greater than or equal to 25 points (out of 30) indicate normal cognition. Below this, scores can indicate severe ( $\leq 9$ points), moderate (10-20 points) or mild (21-24 points) cognitive impairment.

For each factor, only the data of participants who took part in all three conditions were included in the analysis (some residents took part in only one or two conditions of a given factor because of illness or visitors). Furthermore, concerning the evaluations on scales (hunger and meal enjoyment), only the responses of participants who obtained a MMSE score above 20 were included in data analysis (49\% of participants). The number of participants included for each factor and for each measurement is presented on Table 3. 


\subsection{Data analysis}

Scale responses (hunger, meal enjoyment) were converted into scores ranging from 0 (left anchor) to 6 (right anchor). The quantities consumed were converted into calorie intake using nutritional information on the packaging of the food products. For each factor, the hunger scores, the meal enjoyment scores and the calorie intake for the whole meal and for each course (starter, meat, garnish, dairy product, dessert) were submitted to a two-way Analysis of Variance (ANOVA), with condition and participant as factors, using the GLM procedure of SAS software (SAS Institute INC., Cary, NC, USA). Post-hoc analyses were done using the Lsmeans option of the GLM procedure. Means $(M)$ are associated with their standard errors computing in the Lsmeans analyses $(S E)$. The threshold for significance was set at 5\%.

\section{Results}

Table 3 presents the results of the ANOVA for each factor and for each measurement. Figure 1 shows the meal enjoyment score and the intake for the whole meal and for the two components of the main course (meat or fish and garnish) observed in each condition, for each factor. Whatever the factor considered, no significant condition effect was observed on intake for the starter, the dairy product and the dessert.

\section{Table 3 about here}

\section{Figure 1 about here}

\subsection{Dish name}

The ANOVA revealed no significant condition effect on hunger, meal enjoyment or food intake. Concerning food intake, the same results were observed when participants with an MMSE score below 21 were excluded from the analysis. 


\subsection{Portion}

The ANOVA revealed a significant condition effect on hunger but not on meal enjoyment. According to post-hoc analyses, the participants were more hungry for the meals during which they could choose the size of portions themselves (condition size choice) and when they were given two vegetables rather than one (condition variety) than for the control condition. The ANOVA also revealed a condition effect on food intake, for the whole meal and for the two components of main course. According to post-hoc analyses, intake for the whole meal and for the meat was greater when participants were given two small portions of vegetables (condition variety) than when they were given a standard portion of a single vegetable (control condition). In contrast, the consumption of vegetables was smaller when participants chose the size of the portion themselves (condition size choice) than when they were given a standard portion (control condition). On average, participants helped themselves to $45 \mathrm{~g}$ of meat $(\mathrm{SE}=19)$ and $77 \mathrm{~g}$ of vegetables $(\mathrm{SE}=35)$ instead of the $100 \mathrm{~g}$ and $150 \mathrm{~g}$, respectively, recommended by the GEMRCN (2007).

\subsection{Condiment}

The ANOVA revealed a significant condition effect on meal enjoyment and hunger. According to post-hoc analyses, participants better enjoyed meals when condiments were available (conditions condiment + , condition condiment ++ ) than when they only had salt, pepper and mustard (control condition). Participants were also more hungry in the condiment + condition than in the control and in the condiment ++ conditions (no significant difference was observed between these two conditions). Despite a greater satisfaction, a significant condition effect was only seen on garnish intake (in this case rice). No effect was observed on meat intake or on meal intake. According to post-hoc analyses, participants consumed more rice in the condiment + and condiment ++ conditions than in the control condition. Table 4 
shows the number of participants who chose each condiments and the mean quantity of condiments consumed per participant. For both condiment + and condiment ++ , mayonnaise and tomato sauce were the most frequently consumed.

\section{Table 4 about here}

\subsection{Surrounding}

The ANOVA revealed a significant condition effect on meal enjoyment. According to posthoc analyses, participants enjoyed meals less when background music was played than in the control and decor conditions (no significant difference was observed between these two conditions). No difference was observed between the condition in which participants chose objects to decorate their table and the control condition. The ANOVA revealed no significant condition effect on food intake.

\section{Discussion}

Dish name. Wansink, van Ittersum, and Painter (2005) reported that adults (mean age: 43.2 years) generated a higher proportion of positive comments for a dish presented as « Succulent Italian Seafood Filet » than when the same dish was called «Seafood Filet ». Nevertheless, the present study showed that participants did not find the main course more enjoyable when the name on the menu suggested a better quality dish ("Roast pork with gravy") or a gastronomic dish (“Mijoté de porc à la belle fontaine et sa moutarde à l'ancienne”) than in the control condition. The findings were the same when only data from participants with a satisfactory cognitive status (MMSE score $>20$ ) were considered. It is possible that the names chosen (even though selected following pretests) did not induce expectations that were sufficiently different from the control condition to have an impact on eating behaviour. It would be interesting to repeat this study using names that were more different, suggesting 
more clearly cut hedonic expectations in the tested conditions. On the other side, it is possible that the name "Mijoté de porc à la belle fontaine" was too far removed from the dishes usually served in nursing homes.

Portion. Throughout all the experiment, the participants often complained that the portions served were too big. In fact, when participants were able to choose themselves the quantities of meat and vegetables served, their enjoyment of the meal was greater (condition size choice). However, this ability to choose the portion size was accompanied by a decrease in quantity of vegetables consumed. When they chose the size of the portions themselves, all of the participants asked for less meat and vegetables than the quantities recommended by the GEMRCN for elderly people. As a result, it seems that a large portion of vegetables (even when regarded as being too large by the participants) lead to the consumption of a greater quantity of vegetables $(+34 \%$ in our study). This effect of portion size on food intake (the bigger the portion, the more is eaten) was shown by Rolls and colleagues for young adults (see for instance Rolls, Morris \& Roe, 2002; age range: 21-40 years), and for vegetables (Rolls, Roe, \& Meengs, 2010; Mathias et al., 2012). In nursing homes, Cluskey and Dunton (1999) showed that when served smaller portions, residents consumed less food. The present study showed that proposing two portions of vegetables instead of one led to an increase in meat consumption ( $+32 \%$ in the variety condition compared with the control condition). This effect of food variety on food intake has been shown in both young and elderly people (Rolls, Rowe, Rolls, Kingston, Megson, \& Gunary, 1981; Hollis \& Henry, 2007). Hollis and Henry (2007) showed that elderly people (mean age: 70 years) consumed more sandwiches when they were served four different sorts of sandwiches (cheese, cucumber, ham and turkey) than when they were given only one sort of sandwich. More recently, Meengs, Roe, and Rolls (2012) showed that participants (age range: 20-45 years) consumed on average an additional $48.6 \mathrm{~g}$ of vegetables when they were given three of $200 \mathrm{~g}$-portions of broccoli, carrots and 
snap peas than when they were given a portion of $600 \mathrm{~g}$ of a single vegetable. Interestingly, in our study, we found that introducing variety in vegetables had no effect on the consumption of vegetables but increased the consumption of meat. In fact, it is possible that the participants took alternatively mouthfuls of meat with green beans and mouthfuls of meat with zucchinis, namely that we introduced variety in the main dish rather than only in the vegetables. As underlined by Hollis and Henry (2007), the introduction of variety in the meals of elderly people seemed to be an interesting lever to increase food intake.

Condiment. Several studies, including studies in nursing homes, have assessed the impact of flavour enhancement strategies, namely the impact of adding flavourings directly on to food, on food intake. Such increase in food flavour was hypothesized to compensate the decline in olfaction and gustation frequently reported among the elderly. Mathey, Siebelink, de Graaf, and van Staveren (2001) actually observed that adding flavourings to the protein part of the meal led to an increase of bodyweight by about $1 \mathrm{~kg}$ after 16 months of intervention in a nursing home. However, when this study was replicated by Essed, van Staveren, Kik, and de Graaf (2007), this effect was no longer observed. As shown by the literature review presented in Sulmont-Rossé, Maître, and Issanchou (2010), it appears that enhancing food flavour seldom increases food intake in the elderly. Furthermore, in almost all the studies that have assessed the impact of flavour enhancement on food intake in the elderly, flavour compounds and final concentration of the compounds in the foods were chosen without consulting the target population, namely the elderly people (Sulmont-Rossé et al., 2010). Therefore, it is almost possible that the enhanced food did not fit to the elderly's expectations and preferences. Appleton (2009) investigated the impact of adding sauce to the protein part of the meal on food intake in nursing home. Compared to meals without sauce, meals with sauce increased energy intake, but this gain in energy resulted from the sauce consumption. No impact of sauce was observed on meat/fish or vegetable consumption. To the best of our 
knowledge, the present study was the first one that has permitted institutionalized people to season their dishes by themselves, with condiments provided in the middle of the table. Results showed a positive impact of such strategy on hunger before meal, meal enjoyment and rice consumption. Providing institutionalized people with condiments may be successful for three reasons. From a sensory point of view, this strategy allows the elderly to reinforce the flavour of the food. It is worth noting that results showed an increase of consumption for rice, the least tasty food that was proposed for the menu. From a cognitive point of view, providing sauces and seasoning ingredients in the middle of the table allows the dependent elderly people to gain choice and control in their meal. This provision of choice is known to be related with higher intrinsic motivation and higher satisfaction (Iyengar \& Lepper, 1999; Patall, Cooper, \& Robinson, 2008), which may explain higher hunger before meal and higher meal enjoyment. It was shown that providing choice improved food liking in young adults (King, Weber, Meiselman, \& Lv, 2004; King, Meiselman, Hottenstein, Work, \& Cronk, 2007). Finally, we observed that the presence of condiments on the table triggered conversation among the participants (discussions about old recipes, opinions about adding one condiment or another...). This enhanced conviviality may have contributed to the residents' increased meal enjoyment.

Surrounding. Many studies have demonstrated the impact of physical context (crockery, furniture, music...) on meal perception and food intake in young adults (King et al., 2004; Weber, King \& Meiselman, 2004; Stroebele \& de Castro, 2006) and in elderly people (Gibbons \& Henry, 2005). Concerning the elderly, one study carried out in 49 independent senior citizens showed that for the same meal, food intake was significantly greater when it was served in a restaurant than when it was served in a refectory (Gibbons \& Henry, 2005). In our study, however, changing the physical context had no positive effect on meal enjoyment or on food intake. Regarding the music condition, it was demonstrated that reducing attention 
via distraction during eating (such as listening to radio drama or watching television) increases food intake in young population (Robinson et al., 2013). In the present experiment, the experimenter asked the residents to choose from a list the music they wished to hear throughout the meal. Despite this task may have disrupted attention of the elderly people on eating, no impact on food intake was observed. In fact, though music was very much appreciated by some residents, it was not at all appreciated by others, for whom it interfered with conversation during the meal and increased noise, which indeed led to a decline in meal enjoyment.

Further considerations regarding outcome measures. Interestingly, it was observed a mismatch between meal enjoyment and consumption. Introducing variety in the main dish led to an increase of food intake but had no impact on meal enjoyment. On the contrary, playing music during mealtime led to a decrease in food enjoyment but had no impact on meal enjoyment. In the present experiment, it can be hypothesized that the outcome may depend on whether biological versus cognitive processes are involved according to the experimental conditions. In fact, the effect observed in the variety condition probably relies on biological needs (i.e., sake for variety in food resources) and thus had only an impact on food intake. On the contrary, the effect observed in the music condition relies on cognitive processes (feeling of discomfort), which in turn negatively impacts food enjoyment but not food intake. However, providing residents with condiments which may lead to both an increase of sensory pleasure (flavour enhancement) and an increase of self-determination led to an increase of both food intake and meal enjoyment. Despite further research is needed to better understand this mismatch between pleasure and intake, it is worth taking into account the underlying processes when implementing contextual improvement to better predict potential outcome(s). 


\section{Conclusion}

The present study showed that changing a single element of the context of meals in nursing homes could be enough to increase both the residents' enjoyment of their meals and the quantities of meat and/or vegetables consumed, as long as the factor had a direct impact on what was to be eaten (i.e., the content of the dish - what Rozin and Tuorila, 1993, called «Food as context »). The fact of proposing two vegetables instead of one led to a $32 \%$ increase in the consumption of meat. The fact of offering a greater selection of condiments in the middle of the table led to a $35 \%$ increase in the consumption of rice. The present study also showed that the elderly consumed more vegetables when they were given a "large" portion $(150 \mathrm{~g})$ than when they were served a smaller portion. However, factors that modified the context of the meal but had no direct impact on the content of the plate (what Rozin and Tuorila, 1993, called « Non-food contextual influence ») proved to be ineffective in the present study.

Given the budgetary constraint that nursing homes face, this study identified interesting and inexpensive strategies to increase meal enjoyment and food intake in culinary-dependent elderly people. These strategies could contribute to the fight against malnutrition in this population. However, future research is needed to determine to what extent the positive effects observed in our study remain when the corresponding changes (presence of variety in the dish, presence of condiments on the table) become a permanent feature in nursing homes.

\section{ACKNOWLEDGMENTS}

This study is part of AUPALESENS - Improving pleasure of elderly people for better aging and for fighting against malnutrition - funded by the French National Research Agency (ANR-ALID, 2010-2013). The authors thank Valerie Feyen and Françoise Durey for technical 
assistance. Philip Bastable for providing language help. Finally, the authors warmly thank all of the participants in the study as well as the personnel of the establishments for their kind welcome.

\section{REFERENCES}

Abbasi, A. A., \& Rudman, D. (1994). Undernutrition in the nursing-home - prevalence, consequences, causes and prevention. Nutrition Reviews, 52, 113-122.

Abbott, R. A., Whear, R., Thompson-Coon, J., Ukoumunne, O. C., Rogers, M., Bethel, A., Hemsley, A., \& Stein, K. (2013). Effectiveness of mealtime interventions on nutritional outcomes for the elderly living in residential care: A systematic review and meta-analysis. Ageing Research Reviews, 12, 967-981.

Appleton, K. M. (2009). Increases in energy, protein and fat intake following the addition of sauce to an older person's meal. Appetite, 52, 161-165.

Brush, J. A. (2002). Using the environment to improve intake for people with dementia. Alzheimer's Care Quarterly, 3, 330-338.

Charras, K., \& Frémontier, M. (2010). Sharing meals with institutionalized people with dementia: a natural experiment. Journal of Gerontological Social Work, 53, 436-448.

Cluskey, M., \& Dunton, N. (1999). Serving meals of reduced portion size did not improve appetite among elderly in a personal-care section of a long-term-care community. Journal of the American Dietetic Association, 99, 733-735.

Desai, J., Winter, A., Young, K. W., \& Greenwood, C. E. (2007). Changes in type of foodservice and dining room environment preferentially benefit institutionalized seniors with low body mass indexes. Journal of the American Dietetic Association, 107, 808-814. 
Dunne, T. E., Neargarder, S. A., Cipolloni, P. B., \& Cronin-Golomb, A. (2004). Visual contrast enhances food and liquid intake in advanced Alzheimer's disease. Clinical Nutrition, $23,533-538$.

Elmstâhl, S., Blabolil, V., Fex, G., Küller, R., \& Steen, B. (1987). Hospital nutrition in geriatric long-term care medicine: effect of a changed meal environment. Comprehensive Gerontology, A, 29-33.

Essed, N. H., van Staveren, W. A., Kok, F. J., \& de Graaf, C. (2007). No effect of 16 weeks flavour enhancement on dietary intake and nutritional status of nursing home elderly. Appetite, 48, 29-36.

Ferry, M., Mischlich, D., Alix, E., Brocker, P., Constans, T., Lesourd, B., Pfitzenmeyer, P., \& Vellas, B. (2012). Nutrition de la Personne Âgée (4th ed.). Issy-les-Moulineaux: Elsevier Masson.

Folstein, M., Folstein, S., \& McHugh, P. (1975). Mini-Mental-State: a practical method for grading cognitive state of patients for the clinician. Journal of Psychiatric Research, 12, 189198.

GEMRCN. (2007). Recommandation relative à la nutrition. Le Journal Officiel de la République Française, J5-07 du 4 mai 2007.

Gibbons, M. R. D., \& Henry, C. J. K. (2005). Does eating environment have an effect on food intake in the elderly? The Journal of Nutrition, Health \& Aging, 9, 25-29.

HAS. (2007). Stratégies de prise en charge en cas de dénutrition protéino-énergétique chez les personnes âgées. Saint Denis la Plaine : Haute Autorité de Santé, service communication. 
Hollis, J. H., \& Henry, C. J. K. (2007). Dietary variety and its effect on food intake of elderly adults. Journal of Human Nutrition and Dietetics, 20, 345-351.

Iyengar, S. S., \& Lepper, M. R., 1999. Rethinking the value of choice: A cultural perspective on intrinsic motivation. Journal of Personality and Social Psychology, 76, 349-366.

Kenkmann, A., Price, G. M., Bolton, J., \& Hooper, L. (2010). Health, wellbeing and nutritional status of older people living in UK care homes: an exploratory evaluation of changes in food and drink provision. Bmc Geriatrics, 10, 1471-2318.

King, S. C., Meiselman, H. L., Hottenstein, A. W., Work, T. M., \& Cronk, V., 2007. The effects of contextual variables on food acceptability: a confirmatory study. Food Quality and Preference, 18, 58-65.

King, S. C., Weber, A. J., Meiselman, H. L., \& Lv, N. (2004). The effect of meal situation, social interaction, physical environment and choice on food acceptability. Food Quality and Preference, 15, 645-653.

Leslie, W. S. (2011). Nutrition management in special populations: improving the dietary intake of frail older people. Proceedings of the Nutrition Society, 70, 263-267.

Maître, I., Symoneaux, R., \& Sulmont Rossé, C. (2012). Consumer testing in elderly population: Impact of age and dependence on liking scoring. The Fifth European Conference on Sensory Consumer Science of Foods and Beverages. A Sense of Inspiration. September 9th-12th, Bern, Switzerland.

Mathey, M. F., Siebelink, E., de Graaf, C., \& van Staveren, W. A. (2001). Flavour enhancement of food improves dietary intake and nutritional status of elderly nursing home 
residents. The Journals of Gerontology. Series A, Biological Sciences and Medical Sciences, 56, M200-M205.

Mathey, M. F., Vanneste, V., de Graaf, C., de Groot, L., \& van Staveren, W. A. (2001). Health effect of improved meal ambiance in a Dutch nursing home: A 1-year intervention study. Preventive Medicine, 32, 416-423.

Mathias, K. C., Rolls, B. J., Birch, L. L., Kral, T. V. E., Hanna, E. L., Davey, A., \& Fisher, J. O. (2012). Serving larger portions of fruits and vegetables together at dinner promotes intake of both Foods among young children. Journal of the Academy of Nutrition and Dietetics, 112, 266-270.

Meengs, J. S., Roe, L. S., \& Rolls, B. J. (2012). Vegetable variety: an effective strategy to increase vegetable intake in adults. Journal of the Academy of Nutrition and Dietetics, 112, 1211-1215.

Meiselman, H. L. (2006). The role of context in food choice, food acceptance and food consumption. In R. Shepherd \& M. Raats (Eds.), The Psychology of Food Choice (pp. 179199). Oxfordshire: CABI Head Office.

Nieuwenhuizen, W. F., Weenen, H., Rigby, P., \& Hetherington, M. M. (2009). Older adults and patients in need of nutritional support: review of current treatment options and factors influencing nutritional intake. Clinical Nutrition, 29, 160-169.

Nijs, K., de Graaf, C., Kok, F. J., \& van Staveren, W. A. (2006). Effect of family style mealtimes on quality of life, physical performance, and body weight of nursing home residents: cluster randomised controlled trial. British Medical Journal, 332, 1180-1183. 
Nijs, K., de Graaf, C., van Staveren, W. A., \& de Groot, L. (2009). Malnutrition and mealtime ambiance in nursing homes. Journal of the American Medical Directors Association, 10, 226229.

Patall, E. A., Cooper, H., \& Robinson, J. C. (2008). The effects of choice on intrinsic motivation and related outcomes: a meta-analysis of research findings. Psychological Bulletin, 134, 270-300.

Philpin, S. (2011). Sociocultural context of nutrition in care homes. Nursing Older People, $23,24-30$.

Ragneskog, H., Brane, G., Karlsson, I., \& Kihlgren, M. (1996). Influence of dinner music on food intake and symptoms common in dementia. Scandinavian Journal of Caring Sciences, $10,11-17$.

Remsburg, R. E., Luking, A., Baran, P., Radu, C., Pineda, D., Bennett, R. G., \& Tayback, M. (2001). Impact of a buffet-style dining program on weight and biochemical indicators of nutritional status in nursing home residents: A pilot study. Journal of the American Dietetic Association, 101, 1460-1463.

Robinson, E., Aveyard, P., Daley, A., Jolly K., Lewis, A., Lycette, D. \& Higgs, S. (2013). Eating attentively: a systematic review and meta-analysis of the effect of food intake memory and awareness on eating. American Journal of Clinical Nutrition, 97, 728-742.

Rolls, B. J., Morris, E. L., \& Roe, L. S. (2002). Portion size of food affects energy intake in normal-weight and overweight men and women. American Journal of Clinical Nutrition, 76, 1207-1213. 
Rolls, B. J., Roe, L. S., \& Meengs, J. S. (2010). Portion size can be used strategically to increase vegetable consumption in adults. American Journal of Clinical Nutrition, 91, 913922.

Rolls, B. J., Rowe, E. A., Rolls, E. T., Kingston, B., Megson, A., \& Gunary, R. (1981). Variety in a meal enhances food intake in man. Physiology \& Behaviour, 26, 215-221.

Rozin, P., \& Tuorila, H. (1993). Simultaneous and temporal contextual influences on food acceptance. Food Quality and Preference, 4, 11-20.

Shatenstein, B., \& Ferland, G. (2000). Absence of nutritional or clinical consequences of decentralized bulk food portioning in elderly nursing home residents with dementia in Montreal. Journal of the American Dietetic Association, 100, 1354-1360.

Sulmont-Rossé, C., Maître, I., \& Issanchou, S. (2010). Âge, perception chimiosensorielle et préférences alimentaires. Gérontologie et Société, 134, 87-106.

Stroebele, N., \& de Castro, J. M. (2006). Listening to music while eating is related to increases in people's food intake and meal duration. Appetite, 47, 285-289.

Thomas, D. W., \& Smith, M. (2009). The effect of music on caloric consumption among nursing home residents with dementia of the Alzheimer's type. Activities, Adaptation \& Aging, 33, 1-16.

Wansink, B. (2006). Mindless eating. New-York: Bantam Dell.

Wansink, B., van Ittersum, K., \& Painter, J. E. (2005). How descriptive food names bias sensory perceptions in restaurants. Food Quality and Preference, 16, 393-400. 
Weber, A. J., King, S. C., \& Meiselman, H. L. (2004). Effects of social interaction, physical environment and food choice freedom on consumption in a meal-testing environment. Appetite, 42, 115-118.

Wikby, K., \& Fagerskiold, A. (2004). The willingness to eat - An investigation of appetite among elderly people. Scandinavian Journal of Caring Sciences, 18, 120-127. 
Table 1. Review of studies that quantified the impact of improving the context of meals on food intake and/or the nutritional status of elderly people living in nursing homes (0: no effect; + positive effect).

\begin{tabular}{|c|c|c|c|c|c|}
\hline Studies & $\begin{array}{l}\text { Standard } \\
\text { conditions }\end{array}$ & $\begin{array}{l}\text { Improved } \\
\text { conditions }\end{array}$ & $\begin{array}{l}\text { Duration of } \\
\text { the study }\end{array}$ & $\begin{array}{l}\text { Outcome } \\
\text { measures }\end{array}$ & Effects \\
\hline $\begin{array}{l}\text { Elmstahl } \\
\text { et al. } 1987\end{array}$ & $\begin{array}{c}\text { Sobre decor } \\
\text { Meal trays } \\
\text { Individual portions }\end{array}$ & $\begin{array}{c}\text { Decor } 40 \text { 's } \\
\text { Service at the table with the } \\
\text { same dish for all } \\
\text { Residents could help } \\
\text { themselves }\end{array}$ & 4 months & $\begin{array}{l}\text { food intake } \\
\text { body weight }\end{array}$ & $\begin{array}{l}+ \\
0\end{array}$ \\
\hline $\begin{array}{l}\text { Mathey et } \\
\text { al. } 2001\end{array}$ & $\begin{array}{l}\text { Meal trays } \\
\text { No choice } \\
\text { Few personnel }\end{array}$ & $\begin{array}{c}\text { Refined ambiance } \\
\text { Dining room decor, music } \\
\text { Dishes served at the table } \\
1 \text { nurse for } 2 \text { residents }\end{array}$ & 1 year & $\begin{array}{l}\text { food intake } \\
\text { body weight } \\
\text { quality of life }\end{array}$ & $\begin{array}{r}(+) \\
+ \\
+\end{array}$ \\
\hline $\begin{array}{l}\text { Remsburg } \\
\text { et al. } 2001\end{array}$ & Meal trays & $\begin{array}{c}\text { Buffet meals } \\
\text { Choice, possibility to have a } \\
\text { second serving } \\
\text { Improved decor, music }\end{array}$ & 3 months & body weight & 0 \\
\hline $\begin{array}{l}\text { Desai et } \\
\text { al. } 2007\end{array}$ & $\begin{array}{l}\text { Institutional } \\
\text { appearance } \\
\text { Preplated trays }\end{array}$ & $\begin{array}{l}\text { Home-like setting } \\
\text { Bulk food } \\
\text { delivery service }\end{array}$ & $\begin{array}{l}9 \text { to } 12 \\
\text { months }\end{array}$ & $\begin{array}{l}\text { food intake } \\
\text { body weight }\end{array}$ & $\begin{array}{l}+ \\
0\end{array}$ \\
\hline $\begin{array}{l}\text { Nijs et al. } \\
2006\end{array}$ & $\begin{array}{c}\text { Meal trays } \\
\text { Choice of menu } 15 \\
\text { days in advance }\end{array}$ & $\begin{array}{c}\text { Family atmosphere } \\
\text { Decoration, dishes served } \\
\text { at the table, choice } \\
\text { Personnel with residents } \\
\text { at the table }\end{array}$ & 6 months & $\begin{array}{l}\text { food intake } \\
\text { body weight } \\
\text { quality of life }\end{array}$ & $\begin{array}{l}+ \\
+ \\
+\end{array}$ \\
\hline $\begin{array}{l}\text { Kenkmann } \\
\text { et al. } 2010\end{array}$ & $\begin{array}{l}\text { No food displayed } \\
\text { Crowed dining-room } \\
\text { Meals at set times }\end{array}$ & $\begin{array}{l}\text { Restaurant atmosphere } \\
\text { Buffet with increased choice } \\
\text { available, fewer tables in } \\
\text { dining-room, decor of tables, } \\
\text { visitors encouraged to eat with } \\
\text { residents, several sittings }\end{array}$ & 1 year & $\begin{array}{l}\text { body weight } \\
\text { risk of falls } \\
\text { depression } \\
\text { food enjoyment }\end{array}$ & $\begin{array}{l}0 \\
0 \\
0\end{array}$ \\
\hline
\end{tabular}


Table 2. Experimental design. For each factor, two experimental conditions were compared with a control condition. Each factor was associated with a menu (the same for the three corresponding conditions).

\begin{tabular}{|c|c|c|c|c|}
\hline Factor & Menu & $\begin{array}{l}\text { Control } \\
\text { condition }\end{array}$ & $\begin{array}{l}\text { Experimental } \\
\text { condition } 1\end{array}$ & $\begin{array}{c}\text { Experimental } \\
\text { condition } 2\end{array}$ \\
\hline Dish name & $\begin{array}{l}\text { Grated celery root } \\
\text { Sautéed pork } \\
\text { Potatoes } \\
\text { Cheese or yoghurt } \\
\text { Canned fruit in juice }\end{array}$ & $\begin{array}{l}\text { Standard name: } \\
\text { Sautéed pork and } \\
\text { potatoes }\end{array}$ & $\begin{array}{c}\text { Name +: } \\
\text { Roast pork with } \\
\text { gravy and potatoes }\end{array}$ & $\begin{array}{c}\text { Name ++: } \\
\text { Mijoté de porc } \\
\text { à la belle fontaine } \\
\text { et sa moutarde à } \\
\text { l'ancienne }\end{array}$ \\
\hline Portion & $\begin{array}{l}\text { Grated celery root } \\
\text { Guinea fowl in sauce } \\
\text { Green vegetables } \\
\text { Cheese or yoghurt } \\
\text { Canned fruit in juice }\end{array}$ & $\begin{array}{l}\text { GEMRCN Portions: } \\
100 \mathrm{~g} \text { of guinea fowl } \\
150 \mathrm{~g} \text { of green beans }\end{array}$ & $\begin{array}{c}\text { Size choice: } \\
\text { quantities of meat } \\
\text { and vegetables } \\
\text { chosen by } \\
\text { participants }\end{array}$ & $\begin{array}{c}\text { Variety: } \\
100 \mathrm{~g} \text { of guinea fowl } \\
75 \mathrm{~g} \text { of green beans } \\
75 \mathrm{~g} \text { of zucchinis }\end{array}$ \\
\hline Condiment & $\begin{array}{l}\text { Grated carrots } \\
\text { Filet of hake } \\
\text { Rice } \\
\text { Cheese or yoghurt } \\
\text { Stewed fruit }\end{array}$ & salt, pepper, mustard & $\begin{array}{l}\text { Condiment }+: \\
\text { salt, pepper, } \\
\text { mustard } \\
\text { butter, vinaigrette } \\
\text { tomato sauce } \\
\text { mayonnaise }\end{array}$ & $\begin{array}{l}\text { Condiment ++: } \\
\text { salt, pepper, mustard } \\
\text { butter, vinaigrette, } \\
\text { tomato sauce } \\
\text { mayonnaise } \\
\text { garlic, shallot, } \\
\text { lemon, parsley } \\
\end{array}$ \\
\hline Surrounding & $\begin{array}{c}\text { Grated carrots } \\
\text { Blanquette of veal } \\
\text { Rice } \\
\text { Cheese or yoghurt } \\
\text { Stewed fruit }\end{array}$ & $\begin{array}{l}\text { Standard table } \\
\text { decor - } \\
\text { No music }\end{array}$ & $\begin{array}{c}\text { Decor: } \\
\text { Participants chose } \\
\text { two objects } \\
\text { for their table }\end{array}$ & $\begin{array}{c}\text { Music: } \\
\text { Participants } \\
\text { choose music to be } \\
\text { played during the } \\
\text { meals }\end{array}$ \\
\hline
\end{tabular}


Table 3. ANOVA results: $F_{\text {condition }}$ and $p$ value for each factor and each measurement. For each factor, only the data of participants who took part in all three conditions were included in the analysis. Furthermore, for hunger and meal enjoyment, only the responses of participants who obtained a MMSE score above 20 were included in data analysis.

\begin{tabular}{|c|c|c|c|c|}
\hline Factor & Measurement & $\mathbf{n}$ & $F$ condition & $p$ value \\
\hline \multirow[t]{8}{*}{ Dish name } & Hunger & 33 & 0.81 & 0.45 \\
\hline & Meal enjoyment & 33 & 1.06 & 0.37 \\
\hline & Meal intake & 35 & 0.63 & 0.54 \\
\hline & Starter intake & 35 & 0.44 & 0.65 \\
\hline & Meat intake & 35 & 1.98 & 0.15 \\
\hline & Garnish intake & 35 & 1.96 & 0.15 \\
\hline & Dairy product intake & 35 & 0.47 & 0.63 \\
\hline & Dessert intake & 35 & 1.98 & 0.15 \\
\hline \multirow[t]{8}{*}{ Portion } & Hunger & 30 & 4.08 & 0.05 \\
\hline & Meal enjoyment & 30 & 2.06 & 0.14 \\
\hline & Meal intake & 30 & 5.04 & 0.01 \\
\hline & Starter intake & 30 & 0.05 & 0.95 \\
\hline & Meat intake & 30 & 12.91 & 0.001 \\
\hline & Garnish intake & 30 & 4.58 & 0.01 \\
\hline & Dairy product intake & 30 & 2.75 & 0.07 \\
\hline & Dessert intake & 30 & 1.27 & 0.29 \\
\hline \multirow[t]{8}{*}{ Condiment } & Hunger & 27 & 3.96 & 0.05 \\
\hline & Meal enjoyment & 27 & 6.79 & 0.01 \\
\hline & Meal intake & 30 & 0.77 & 0.46 \\
\hline & Starter intake & 30 & 0.23 & 0.79 \\
\hline & Meat intake & 30 & 0.84 & 0.44 \\
\hline & Garnish intake & 30 & 4.09 & 0.02 \\
\hline & Dairy product intake & 30 & 0.57 & 0.57 \\
\hline & Dessert intake & 30 & 0.79 & 0.46 \\
\hline \multirow[t]{8}{*}{ Surrounding } & Hunger & 32 & 0.93 & 0.40 \\
\hline & Meal enjoyment & 32 & 3.44 & 0.05 \\
\hline & Meal intake & 36 & 1.56 & 0.22 \\
\hline & Starter intake & 36 & 0.01 & 0.99 \\
\hline & Meat intake & 36 & 0.93 & 0.40 \\
\hline & Garnish intake & 36 & 2.22 & 0.12 \\
\hline & Dairy product intake & 36 & 0.32 & 0.72 \\
\hline & Dessert intake & 36 & 2.79 & 0.07 \\
\hline
\end{tabular}


Table 4. Data on the consumption of condiments proposed in the conditions condiment + and condiment ++ .

\begin{tabular}{llcc}
\hline Condition & Product & $\begin{array}{c}\text { Number of participants who } \\
\text { used the condiment }\end{array}$ & $\begin{array}{c}\text { Mean quantity consumed } \\
\text { per participant }\end{array}$ \\
\hline Butter & 7 & $14.3 \mathrm{~g}$ \\
& Mayonnaise & 17 & $40.1 \mathrm{~g}$ \\
& Vinaigrette & 7 & $6.1 \mathrm{~g}$ \\
& Tomato sauce & 20 & $45.0 \mathrm{~g}$ \\
\hline \multirow{3}{*}{ Condiment + } & Butter & 10 & $15.6 \mathrm{~g}$ \\
& Mayonnaise & 17 & $44.7 \mathrm{~g}$ \\
& Vinaigrette & 6 & $9.0 \mathrm{~g}$ \\
& Tomato sauce & 16 & $49.6 \mathrm{~g}$ \\
& Garlic & 9 & $12.9 \mathrm{~g}$ \\
& Shallot & 9 & $13.1 \mathrm{~g}$ \\
& Parsley & 15 & $2.3 \mathrm{~g}$ \\
& Lemon & 8 & 1.3 quarters
\end{tabular}


Figure 1. Meal enjoyment score, total calorie intake, meat and garnish intake for each factor and for each condition. The error bars correspond to standard error of the mean. For each variable, the means with the same letter are not significantly different $(p<.05)$. F ratios: ns: not significant; $* \mathrm{p}<.05 ; * * \mathrm{p}<0.01 ; * * * \mathrm{p}<0.001$.
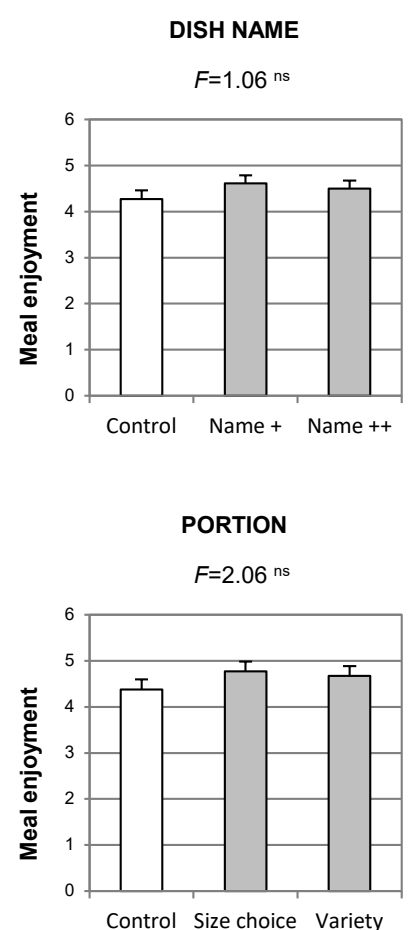

CONDIMENT

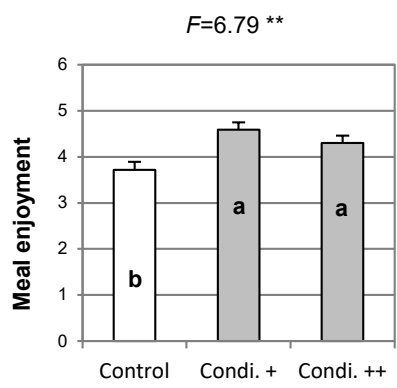

SURROUNDING

$F=3.44$ *

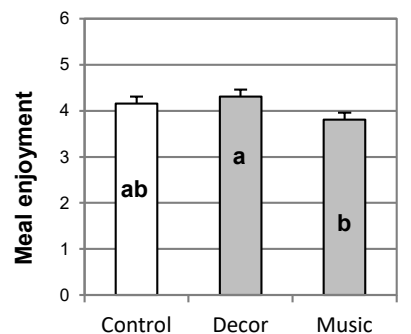

$F=0.63$ ns

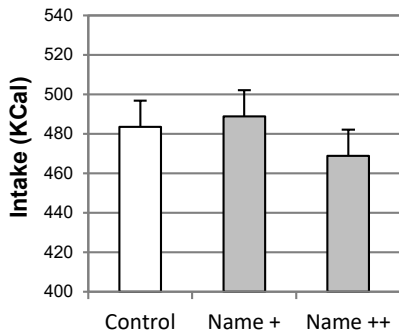

Meal

$F=5.04$ **

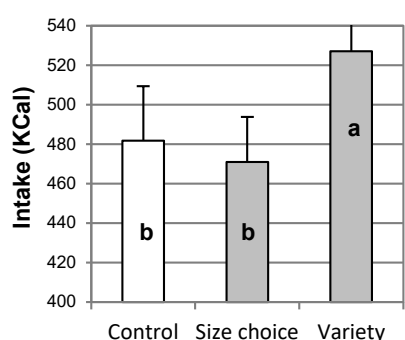

Meal

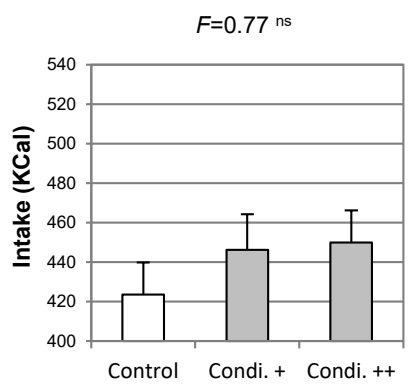

Meal

$F=1.56$ ns

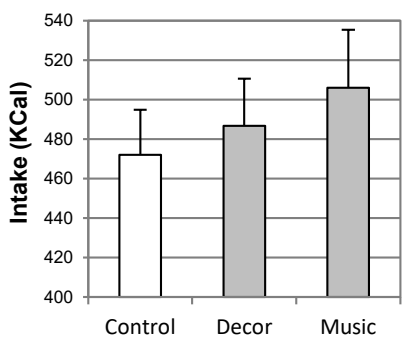

Meat

$F=1.98^{\text {ns }}$

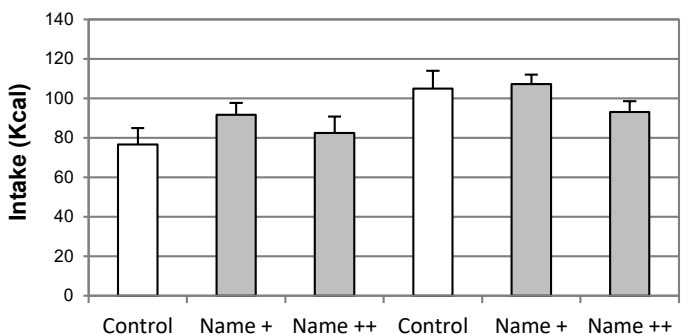

Control Name + Name ++ Control Name + Name ++

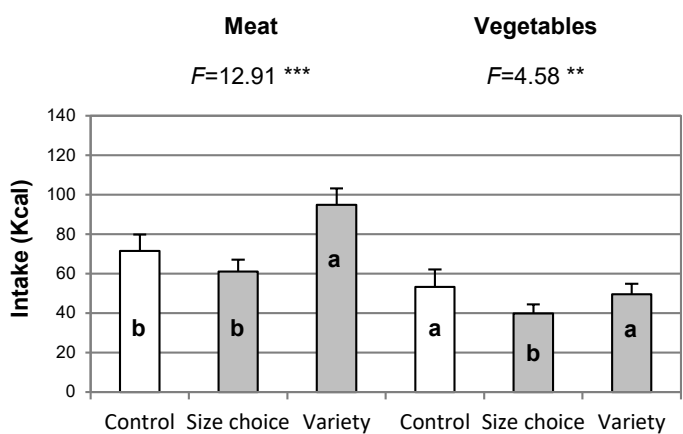

Control Size choice Variety Control Size choice Variety

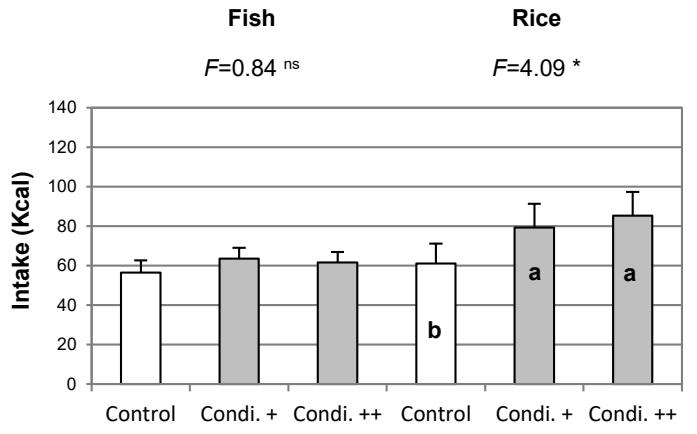

Meat

Rice

$F=0.93$ ns

$F=2.22$ ns

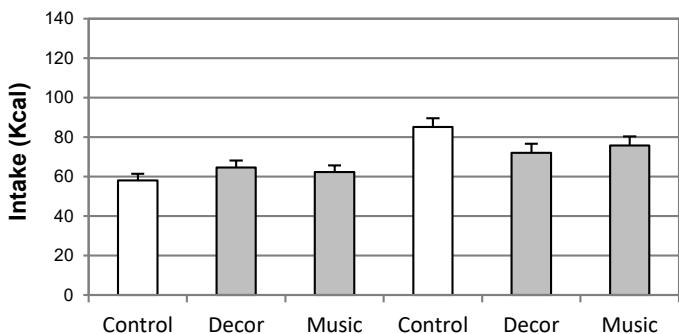

